IRA-International Journal of Applied Sciences ISSN 2455-4499; Vol.04, Issue 02 (2016)

Institute of Research Advances

Pg. no. 226-229

http://research-advances.org/index.php/IRAJAS

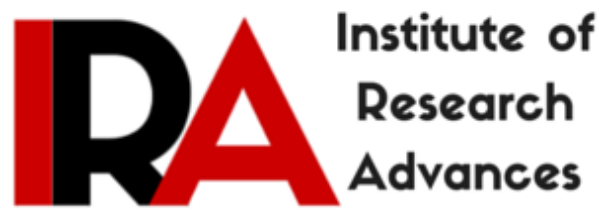

\title{
Response of Golden Acre Cabbage to Foliar Application of Water Soluble Fertilizers on Plant Growth and Seed Yield
}

\author{
${ }^{1}$ S. Narayan, ${ }^{2}$ N. Ahmed, ${ }^{3}$ Shahnaz Mufti, ${ }^{4}$ M.A. Chattoo, ${ }^{5}$ P. K. Singh and \\ * F. A. Khan \\ $\mathbf{1 , 2 , 3 , 4 , 5}$ Division of Vegetable Science; \\ *Division of PHT \\ Sher-e-Kashmir University of Agricultural Science and Technology of Kashmir, \\ Shalimar, Srianagr-190025 (J\&K), India.
}

Type of Review: Peer reviewed.

DOI: http://dx.doi.org/10.21013/jas.v4.n2.p2

\section{How to cite this paper:}

Narayan, S., Ahmed, N., Mufti, S., Chattoo, M., Singh, P., \& Khan, F. (2016).

Response of Golden Acre Cabbage to Foliar Application of Water Soluble Fertilizers on Plant Growth and Seed Yield. IRA-International Journal of Applied Sciences (ISSN 2455-4499), 4(2), 226-229. doi:http://dx.doi.org/10.21013/jas.v4.n2.p2

(C) Institute of Research Advances

(cc) EY-NO

This work is licensed under a Creative Commons Attribution-Non Commercial 4.0 International License subject to proper citation to the publication source of the work.

Disclaimer: The scholarly papers as reviewed and published by the Institute of Research Advances (IRA) are the views and opinions of their respective authors and are not the views or opinions of the IRA. The IRA disclaims of any harm or loss caused due to the published content to any party. 


\section{ABSTRACT}

The present study was performed to assess the effect of foliar application of water soluble fertilizers on growth and seed yield of cabbage cv. Golden Acre. Four WSF (Multi-K, $\mathrm{NP}_{2} \mathrm{O}_{5} \mathrm{~K}_{2} \mathrm{O}, \mathrm{NP}_{2} \mathrm{O}_{5} \mathrm{~K}_{2} \mathrm{O}$ and $\mathrm{NP}_{2} \mathrm{O}_{5} \mathrm{~K}_{2} \mathrm{O}$ ) were tested against control (water). Plant height, no. of branches, pods as well as seed yield was found to increase with the applications of WSFs. Data also revealed that maximum plant height $(162.13 \mathrm{~cm})$, no. of branches (27.21/plant), no. of pods (1460.49/plant) and seed yield $(10.37 \mathrm{q} / \mathrm{h})$ were recorded with the foliar application of $\mathrm{NP}_{2} \mathrm{O}_{5} \mathrm{~K}_{2} \mathrm{O}$ (15-15-30) against the minimum plant height $(146.03 \mathrm{~cm})$, no. of branches (21.73/plant), no. of pods (915.46/plant) and seed yield (5.50q/h) in untreated plots. The same treatment i.e. $\mathrm{NP}_{2} \mathrm{O}_{5} \mathrm{~K}_{2} \mathrm{O}$ (15-15-30) also recorded highest net return (Rs. $3.1 \mathrm{lakh} / \mathrm{h})$ as well as cost benefit ratio (1:4.78), and therefore may be recommended for seed production of cabbage.

Key words: Cabbage, seed yield, water soluble fertilizers, cost benefit ratio.

\section{INTRODUCTION}

Seed play a vital role in increasing the vegetable production. The growth of plant and quality of seed are strongly influenced not only by genetic factors and environment conditions but also by the nutrition that is available to the plants during its growth period. Emphasis should always be laid on those factors which contribute to and affect seed quality. High seed quality comprising high viability and high vigour is essential for increasing crop production. High seed yield of vegetables can not be realized only with the use of soil application of chemical fertilizers. The efficiency of fertilizers applied in soil is low due to various losses and fixation in soil. Foliar application of nutrients eliminates the problems like fixation and immobilization. Hence, foliar nutrition is recognized as an important method of fertilization in modern agriculture. The cabbage being shallow rooted crop, remove large amounts of nutrients which go in the formation of head. Since the nutrient requirement of seed crop of cabbage is much more compared to crop meant for vegetable purpose only, as the seed crop remains in the field for about two times more than the vegetable crop. Thus deficiency of available nutrients in the soil during flowering and seed settings results in poor seed set which leads to the reduction in seed yield. In such conditions foliar application of watersoluble fertilizers (WSF) is considered highly suitable for increasing seed yield because of high solubility, easy and quick absorption by plant tissues. The spraying of such WSF leads to proper development of flower buds and seed setting which ultimately improves the seed yield. Recently new generation specialty fertilizers have been introduced exclusively for foliar feeding and fertigation. These fertilizers have different ratios of $\mathrm{N}, \mathrm{P}$ and $\mathrm{K}$ with high water solubility and also amenable for foliar nutrition (Jeyabal et al.1998). In view of the above facts, the present investigation was undertaken to study the effect of foliar application of WSF on plant growth and seed yield of cabbage.

\section{MATERIAL S AND METHODS}

Studies were conducted at the experimental farm of the Division of Olericulture, SKUAST-Kashmir, Shalimar. Forty days old seedling of cabbage cv. Golden Acre having uniform seedlings vigor were transplanted in plots of $2.4 \times 1.8 \mathrm{~m}^{2}$ size with the spacing of $60 \times 40 \mathrm{~cm}$. Recommended dose of N, P and $\mathrm{K} @ 120: 60: 60 \mathrm{~kg} / \mathrm{ha}$ was applied in all the treatments. Application of four water-soluble fertilizers (WSF) as foliar spray, namely Multi-K (N-13, K-45), $\mathrm{NP}_{2} \mathrm{O}_{5} \mathrm{~K}_{2} \mathrm{O}$ (19-19-19), $\mathrm{NP}_{2} \mathrm{O}_{5} \mathrm{~K}_{2} \mathrm{O}$ (19-09-19), $\mathrm{NP}_{2} \mathrm{O}_{5} \mathrm{~K}_{2} \mathrm{O}$ (17-10-27) and $\mathrm{NP}_{2} \mathrm{O}_{5} \mathrm{~K}_{2} \mathrm{O}$ (15-15-30) along with control (water) were tested in a Randomized Block Design with four replications. Out of the total five sprays at a concentration of $5 \mathrm{~g} / \mathrm{l}(0.5 \%)$ three were made at weekly intervals after 30 days of transplanting while as two sprays with a week of gap were done at bolting stage. The observations were recorded from random sample of five comparative plants from each treatment and replications using standard procedures. The data obtained were put to statistical analysis, using the method as suggested by Panse and Sukhatme (1978). 


\section{RESULTS AND DISCUSSION}

Foliar feeding of WSF had significant effect on vegetative growth as well as seed yield of cabbage (Table 1). The maximum plant height $(162.13 \mathrm{~cm})$ was recorded with the application of $\mathrm{NP}_{2} \mathrm{O}_{5} \mathrm{~K}_{2} \mathrm{O}(15-15-30)$ followed by $\mathrm{NP}_{2} \mathrm{O}_{5} \mathrm{~K}_{2} \mathrm{O}$ (19-09-19), $\mathrm{NP}_{2} \mathrm{O}_{5} \mathrm{~K}_{2} \mathrm{O}$ (17-10-27) and Multi- $\mathrm{K}(\mathrm{N}-13, \mathrm{~K}-45)$ which were found statistically at par with $\mathrm{NP}_{2} \mathrm{O}_{5} \mathrm{~K}_{2} \mathrm{O}(15-15-30)$ by producing plant height of $156.90,156.89$ and $154.71 \mathrm{~cm}$ height of plants against the minimum plant height of $146.03 \mathrm{~cm}$ in control. Similarly, $\mathrm{NP}_{2} \mathrm{O}_{5} \mathrm{~K}_{2} \mathrm{O}(15-15$ 30) also produces maximum no. of branches (27.21/plant) followed by $\mathrm{NP}_{2} \mathrm{O}_{5} \mathrm{~K}_{2} \mathrm{O}$ (19-09-19) with 25.32 branches/plant against the minimum no. of branches (21.73/plant) in control. This may be due to the fact that the application of nutrients directly to the site of metabolism increases the nutrient use efficiency and thus reducing the loss of nutrients through leaching and fixation as is in the soil application of fertilizers. These results are in conformity with the findings of Yadav et al (2004), Olaniyi et al (2011), El-Tohamy et al. (2011) and Khalid and Sheded (2015).

It is also obvious from the data that number of pods per plant was significantly affected due to application of WSF and maximum number of pods (1460.49/ plant) was recorded with $\mathrm{NP}_{2} \mathrm{O}_{5} \mathrm{~K}_{2} \mathrm{O}$ (15-15-30) followed by $\mathrm{NP}_{2} \mathrm{O}_{5} \mathrm{~K}_{2} \mathrm{O}$ (19-09-19) which recorded 1341.88 number of pods per plant and was significantly superior over control, recording 915.46 number of pods per plant. Foliar application of WSF significantly improved seed yield of cabbage. Sprays of 0.5 percent $\mathrm{NP}_{2} \mathrm{O}_{5} \mathrm{~K}_{2} \mathrm{O}$ (15-15-30) gave significantly higher seed yield of $10.37 \mathrm{q} /$ ha followed by $\mathrm{NP}_{2} \mathrm{O}_{5} \mathrm{~K}_{2} \mathrm{O}$ (17-10-27) which recorded seed yield of $9.06 \mathrm{q} / \mathrm{ha}$ and was significantly superior over control recording seed yield of $5.50 \mathrm{q} / \mathrm{ha}$. The increase in seed yield was 88.55 percent over control. The variation in seed yield may be due to the fact that excess $\mathrm{N}$ affects seed production through its promotive affect on vegetative growth, which further helps to augument the flowering and seed setting. Almost similar results have been reported in tomato and Chilli by Palaniappan et al (1999), in radish by Shukla et al. (2013), in soybean by Mannan (2014) and ) in Nigella sativa L. by Khalid and Sheded (2015).

The economics of cabbage seed production affected by foliar application of WSF have been presented in Table -1 . The maximum net returns (Rs. 3,11,100) and cost benefit ratio $(1: 4.78)$ was found with the use of NPK(15-15-30) while as the plots without spray gave the minimum net returns (165000) and cost benefit ratio (1:2.70).

In light of these results it can be concluded that the three (weekly) sprays of $\mathrm{NP}_{2} \mathrm{O}_{5} \mathrm{~K}_{2} \mathrm{O}(15-15-30)$ at 30 days after transplanting plus two (weekly) sprays of $\mathrm{NP}_{2} \mathrm{O}_{5} \mathrm{~K}_{2} \mathrm{O}$ (15-15-30) at the time of bolting can increase seed yield in cabbage with highest net returns and cost benefit ratio and therefore, can be recommended to the farmers for seed production in cabbage.

\section{REFERENCES}

El-Tohamy, W. A., H. M. El-Abagy, M. A., Badr, S. D. Abou-Hussein and Y. Helmy. 2011. The influence of foliar application of potassium on yield and quality of carrot (Daucus carota L.) plants grown under sandy soil conditions. Aust. J. Basic and Applied Sci., 5(3): 171.

Jeybal, A., R. M. Murlidhar, S. P. Palaniapan and S. Chelliah. 1998. Technical bulletin on speciality fertilizers. Nagarjuna Agricultural Research and Development Institute. Secunderabad.

Khalid, A. K., and M. R. Shedeed. 2015. Effect of NPK and foliar nutrition on growth, yield and chemical constituents in Nigella sativa L. J. Mater. Environ. Sci., 6 (6): 1709-14.

Mannan, M. A. 2014. Foliar and soil fertilization effect on seed yield and protein content of soybean, Bangladesh Agron. J., 17 (1): 67-72. 
Olaniyi, J. O. and A. E. Ojetayo. 2011. Effect of fertilizer types on the growth and yield of two cabbage varieties. J. Animal \& Plant Scie., 12 (2): 1573-82.

Palaniappan S. P., A. Jeybal and S. Chelliah (1999). Response of tomato and chilli to foliar application of speciality fertilizers. Veg.Sci., 26 (2):198-200.

Panse V.G. and P. V. Sukhatme. 1978. Statistical method for Agricultural workers. Indian Council of Agricultural Research, New Delhi.

Shukla, Y.R., P. Kumar, S. Kansal, M. Singh and S. Kumar. 2013. Effect of integrated nutrient management practices on seed yield and quality of radish, Raphanus sativus L cv Chinese Pink. Int.l J. Farm Sci., 3(2): 10-18.

Yadav, B.D., R. B. Khandelwal and Y.K. Sharma. 2004. Response of tomato of foliar feeding of watersoluble fertilizers. Veg.Sci., 31(1): 98-100.

Table: Effect of foliar feeding of water-soluble fertilizers on seed yield and C: B ratio of cabbage (Mean of three years)

\begin{tabular}{|c|l|c|c|c|c|c|c|}
\hline S.No. & \multicolumn{1}{|c|}{ Treatment } & $\begin{array}{c}\text { Plant } \\
\text { height } \\
\text { (cm) }\end{array}$ & $\begin{array}{c}\text { No. of } \\
\text { branches/ } \\
\text { plant }\end{array}$ & $\begin{array}{c}\text { No. of } \\
\text { pods / } \\
\text { plant }\end{array}$ & $\begin{array}{c}\text { Seed } \\
\text { yield } \\
\text { q/ha }\end{array}$ & $\begin{array}{c}\text { Net } \\
\text { returns } \\
\text { (Rs/ha) }\end{array}$ & $\begin{array}{c}\text { C:B } \\
\text { ratio }\end{array}$ \\
\hline 1. & Control (No spray) & 146.03 & 21.73 & 915.46 & 5.50 & 165000 & $1: 2.70$ \\
\hline 2. & Multi- K (N-13,K-45) & 154.71 & 23.91 & 1256.36 & 8.10 & 243000 & $1: 3.73$ \\
\hline 3. & NPK (19-19-19) & 149.36 & 22.60 & 1122.79 & 6.57 & 197100 & $1: 3.03$ \\
\hline 4. & NPK (19-09-19) & 156.90 & 25.32 & 1341.88 & 8.82 & 264600 & $1: 4.07$ \\
\hline 5. & NPK (17-10-27) & 156.89 & 24.43 & 1257.79 & 9.06 & 271800 & $1: 4.18$ \\
\hline 6. & NPK (15-15-30) & 162.13 & 27.21 & 1460.49 & 10.37 & 311100 & $1: 4.78$ \\
\hline 7. & CD at 5\% & $\mathbf{9 . 1 1}$ & $\mathbf{2 . 2 1}$ & $\mathbf{1 0 7 . 0 3}$ & $\mathbf{0 . 0 9}$ & & \\
\hline
\end{tabular}

Sale rate - Rs. $50,000 / \mathrm{q}$ 